\title{
COPROLOGICAL HELMINTH SCREENING IN BRAZILIAN FREE RANGING GOLDEN LION TAMARINS, Leontopithecus rosalia (L., 1766) (PRIMATES, CALLITHRICHIDAE)
}

\author{
MONTEIRO, R. V., ${ }^{1}$ JANSEN, A. M. ${ }^{1}$ and PINTO, R. M. ${ }^{2}$ \\ ${ }^{1}$ Laboratório de Biologia de Tripanosomatídeos, Departamento de Protozoologia, Instituto \\ Oswaldo Cruz-Fiocruz, Rio de Janeiro, RJ, Brazil \\ ${ }^{2}$ Laboratório de Helmintos Parasitos de Vertebrados, Departamento de Helmintologia, Instituto \\ Oswaldo Cruz-Fiocruz, Av. Brasil, 4365, CEP 21045-900, Rio de Janeiro, RJ, Brazil \\ Correspondence to: Roberto Magalhães Pinto, Laboratório de Helmintos Parasitos de Vertebrados, \\ Departamento de Helmintologia, Instituto Oswaldo Cruz-Fiocruz, Av. Brasil, 4365, CEP 21045-900, \\ Rio de Janeiro, RJ, Brazil, e-mail: rmpinto@ioc.fiocruz.br \\ Received July 29, 2002 - Accepted December 2, 2002 - Distributed November 30, 2003
}

(With 6 figures)

One of the most endangered species in the world due to the destruction of natural habitats and illegal hunting, the golden lion tamarin, Leontopithecus rosalia has, until quite recently, been of great concern to researchers. This species is endemic in the Atlantic forest in Rio de Janeiro State; Coimbra-Filho (1969) Kierulff (1993), Kierulff \& Rylands (2003) showed its possible primitive distribution which is almost intact today. Furthermore, during the last thirty years the species has been the object of extensive efforts to ensure its survival. Biological reserves have been created; ecological, biological, and reproductive data are being surveyed.

This unusual situation may explain the few reports on helminth fauna parasitizing these monkeys in Brazil. The only available records are those of Machado-Filho (1950) for the acanthocephalan Oncicola spirula (Olfers, 1819) [= Prosthernorchis spirula], Nagaty (1935) for the filariid Parlitomosa zakii Nagaty, 1935, and Vicente et al. (1982) for the physalopterid Physaloptera sp.

Foreign accounts refer to the spirurid nematodes Rictularia sp. and Pterygodermatitis nycticebi (Monnig, 1920) Quentin, 1969, recovered from captive golden lion tamarins in the USA (Montali et al., 1983; Yue et al., 1980; Yue \& Jordan, 1986).

This note reports helminthological findings obtained by analizing fecal samples collected from free-range golden lion tamarins in Brazil.

Individual fecal samples were periodically collected from 83 animals of two different areas in cooperation with the Associação Mico Leão Dourado (AMLD): 47 from Poço das Antas Biological Reserve
(PABR) and 36 from União Biological Reserve (UBR). The PABR is located in Silva Jardim County, and the UBR in Rio das Ostras and Casimiro de Abreu, neighboring counties in the State of Rio de Janeiro and located at about $42^{\circ}-42^{\circ} 30^{\prime} \mathrm{W}, 22^{\circ} 20^{\prime}-22^{\circ} 40^{\prime} \mathrm{S}$.

Primates were individually trapped and chemically restrained for biological sample collection. Feces were obtained either from the cages or during handling, and preserved in labelled plastic vials with $40 \mathrm{ml}$ of $10 \%$ formalin solution until analysis.

Preserved samples were centrifuged during 10 minutes at 2,500 rpm, and the supernatant discharged. Vial content was re-suspended in $10 \mathrm{ml}$ of a $0.85 \%$ $\mathrm{NaCl}$ solution plus $5 \mathrm{ml}$ of sulphuric ether and centrifuged during 2 minutes at $1,500 \mathrm{rpm}$. Supernatant was discharged and the remaining content re-suspended in $0.5 \mathrm{ml}$ of $10 \%$ formalin in Eppendorfs that were kept under refrigeration at $8^{\circ} \mathrm{C}$. Fecal samples were individually analyzed for helminth eggs under a Olympus brightfield microscope and photomicrographs were obtained using a Zeiss Axiophoto system.

Egg identification is in accordance with Sloss et al. (1999) and helminth classification follows Amin (1985) for the acanthocephalan and Vicente et al. (1997) for the nematodes.

Results showed the presence of helminth eggs, representing one species of acanthocephalan, Oncicola sp., and five species of nematodes; Ancylostomatidae sp., Ascarididae sp., Oxyuridae sp., Spiruridae sp., and Trichostrongylidae sp. Except for the acanthocephalan and the spirurid nematodes, the other are new parasite records for L. rosalia (Figs. 1-6, Table 1). 

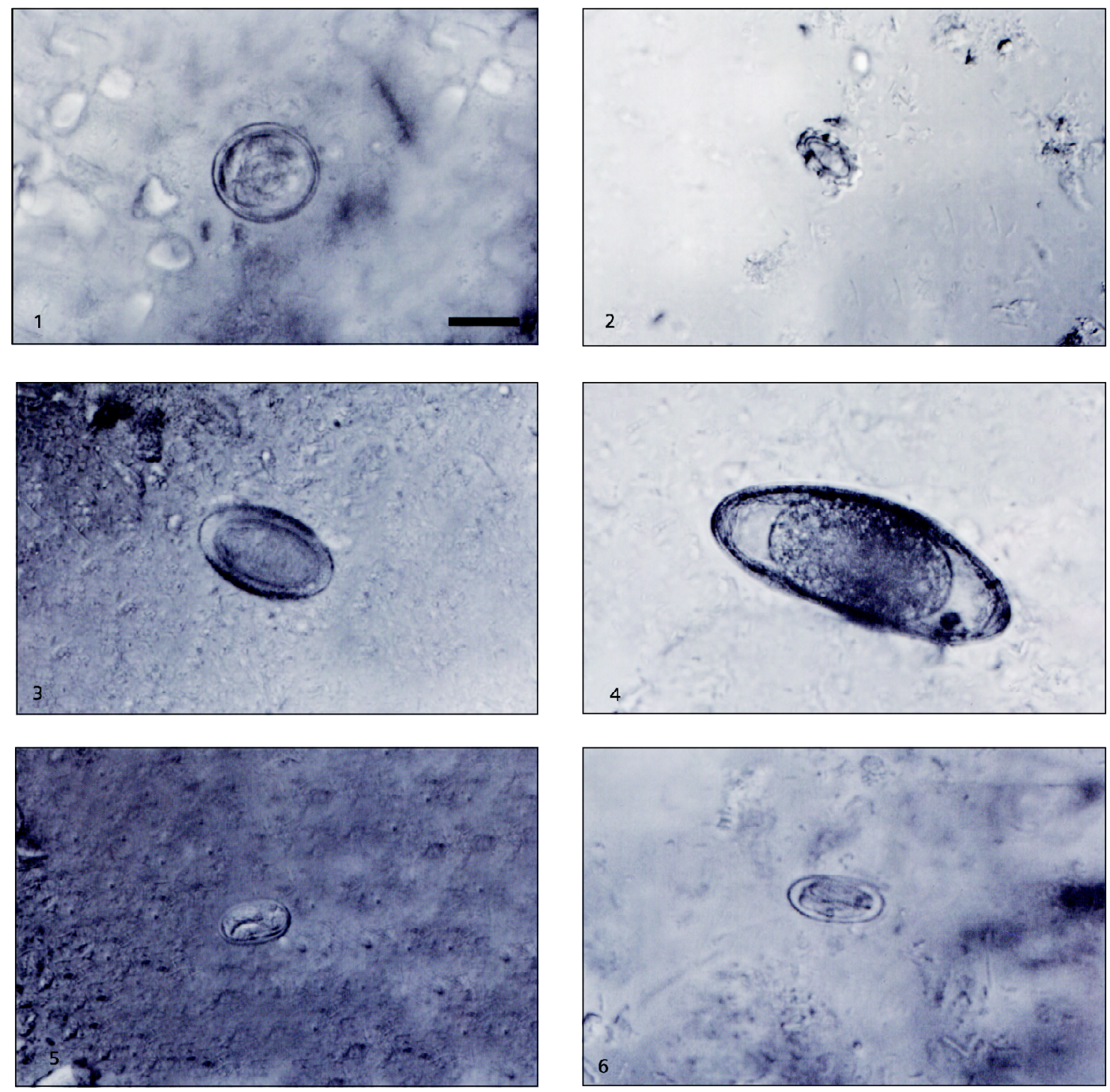

Fig. 1 - Ancylostomatidae sp. egg (bar = $0.02 \mathrm{~mm})$. Fig. 2 - Ascarididae sp. egg (bar = 0.03 mm). Fig. 3 - Oncicola $\mathrm{sp}$. egg $($ bar = $0.02 \mathrm{~mm})$. Fig. $4-$ Oxyuridae sp. egg $($ bar = $0.02 \mathrm{~mm})$. Fig. 5 - Spiruridae sp. egg $(\mathrm{bar}=0.04 \mathrm{~mm})$. Fig. $6-$ Trichostrongylidae sp. egg $($ bar $=0.01 \mathrm{~mm})$. Bar of Fig. $1(=1 \mathrm{~cm})$, common to Figs. 2-6.

Egg size alone is not considered a reliable criterian for specific helminth diagnosis and may be used together with other characters in case adult worms are found during necropsy.

The null hypothesis of equal prevalences of nematode eggs in the two investigated areas was tested by means of the Mann-Whitney U test. Only prevalences of Trichostrongylidae and Spiruridae eggs proved significantly different in both areas. The prevalence of the former was higher in the
PABR $(\alpha=0.05, p=0.027)$ whereas that of the latter was higher in the UBR $(\alpha=0.05, \mathrm{p}=0.047)$ (Table 1).

The different prevalence patterns of these two parasite species may also be related to the different monkey densities in the considered populations. Forty-eight groups of tamarins distributed in 2,760 ha live in the PABR area whereas 12 groups of monkeys live in the UBR unit distributed in 2,400 ha (Rylands, 1994; Kierulff \& Oliveira, 1994). 
TABLE 1

Prevalence of helminth eggs in feces of golden lion tamarins (L. rosalia) maintained in the Poço das Antas Biological Reserve (PABR) and União Biological Reserve (UBR).

\begin{tabular}{|l|c|c|c|c|c|c|c|c|}
\hline & \multicolumn{7}{|c|}{ Helminth eggs $^{\mathbf{a}}$} & \\
\hline $\begin{array}{l}\text { Biological } \\
\text { reserve }\end{array}$ & Anc & Asc & Oxy & Onc & Spi & Tri & $\begin{array}{c}\text { Negative } \\
\text { Number of } \\
\text { samples }\end{array}$ \\
\hline PABR & $12.8(6)$ & $4.3(2)$ & $10.6(5)$ & $51.1(4)$ & $19.1(9)^{*}$ & $23.4(11)^{*}$ & $23.4(11)$ & 47 \\
\hline UBR & $11.1(4)$ & $5.6(2)$ & $5.6(2)$ & $55.6(20)$ & $38.9(14)^{*}$ & $5.6(2)^{*}$ & $22.2(8)$ & 36 \\
\hline
\end{tabular}

a. Ancylostomatidae sp. (Anc), Ascarididae sp. (Asc), Oxyuridae sp. (Oxy), Oncicola sp. (Onc), Spiruridae sp. (Spi), Trichostrongylidae sp. (Tri). *Significant differences with the Mann-Whitney $\mathrm{U}$ test $(\alpha=0.05)$. Values are percentages relative to each biological reserve (nominal data are in parenthesis).

Previous data show that trichostrongylid nematodes can interfere in the wild host population size (Hudson et al., 1998) and also be highly pathogenic to captive animals (Soulsby, 1965).

Based on this fact, it is reasonable to suppose that the observed high prevalence of these worms in monkeys living in the PABR area can debilitate the infected animals, affecting their reproductive success and survival, whereas spirurid worms are of low pathogenicity to healthy hosts.

The higher prevalence of trichostrongylid nematodes in the PABR area is also associated with a high morbidity of monkeys due to trypanosomiasis (Lisboa et al., 2000).

Acknowledgments - We thank James Dietz, Andrew Baker, Paula Procópio, and AMLD for help in collecting feces samples.

\section{REFERENCES}

AMIN, O. M., 1985, Classification. In: D. W. T. Crompton, B. B. Nickol (eds.), Biology of Acanthocephala. Cambridge University Press, London, 519p.

COIMBRA-FILHO, A. F., 1969, Mico-Leão, Leontideus rosalia (Linnaeus, 1776), situação atual da espécie no Brasil (Callithricidae - Primates). An. Acad. Brasil, Ci 41(Suplemento): 29-52.

HUDSON, P. J., DOBSON, A. P. \& NEWBORN, D., 1998, Prevention of population cycles by parasite removal. Science, 282: 2256-2258.

KIERULFF, M. C. M., 1993, Status and distribution of the golden lion tamarin in Rio de Janeiro. Neotrop Primates, 1: 2324.

KIERULFF, M. C. M. \& OLIVEIRA, P. P., 1994, Habitat preservation and the translocation of threatened groups of golden lion tamarins, Leontopithecus rosalia. Neotrop. Primates, 2(suppl.): 15-18.

KIERULFF, M. C. M. \& RYLANDS, A. B., 2003, Census and distribuition of the golden lion tamarin (Leontopithecus rosalia). Am. J. Primatol., 59: 29-44.
LISBOA, C. V., DIETZ, J., BAKER, A. J., RUSSEL, N. N. \& JANSEN, A. M., 2000, Trypanosoma cruzi infection in Leontopithecus rosalia at Reserva Biológica de Poço das Antas, Rio de Janeiro, Brazil. Mem. Inst. Oswaldo Cruz, 95: 445-452.

MACHADO-FILHO, D. A., 1950, Revisão do gênero Prosthernorchis Travassos, 1915 (Acanthocephala). Mem Inst. Oswaldo Cruz, 48: 495-544.

MONTALI, R. J., GARDINER, C. H., EVANS, R. E. \& BUSH, M., 1983, Pterygodermatites nycticebi (Nematoda, Spirurida) in golden lion tamarins. Lab. Anim. Sci., 33: 194-197.

NAGATY, H. F., 1935, Parlitomosa zakii (Filariinae). A new genus and species and its microfilaria from Leontocebus rosalia. J. Egypt. Med. Ass., 18: 483-496.

RYLANDS, A. B., 1994, Conservation units and the protection of Atlantic forest lion tamarins. Neotrop Primates, 2(suppl.): $12-14$.

SOULSBY, E. J. L., 1965, Textbook of veterinary clinical parasitology. Blackwell Scientific Publications, Oxford, 1, 120p.

SLOSS, M. W., ZAJAC, A. M. \& KEMP, R. L., 1999, Parasitologia clínica veterinária, 6. ed. Editora Manole Ltda, São Paulo, x + 198p.

VICENTE, J. J., PINTO, R. M. \& FARIA, Z., 1982, Spirura delicata sp. n. (Spiruridae, Spirurinae) from Leontocebus mystax (Callithrichidae) and a check list of other nematodes of some Brazilian primates. Mem. Inst. Oswaldo Cruz, 87 (Supl. 1): 305-308.

VICENTE, J. J., RODRIGUES, H. O., GOMES, D. C. \& PINTO, R. M., 1997, Nematóides do Brasil. Parte V: nematóides de mamíferos. Revta. bras. Zool., 14(Supl. 1): 1-452.

YUE, M. Y., JENSEN, J. M. \& JORDAN, H. E., 1980, Spirurid infections (Rictularia sp.) in golden marmosets, Leontopithecus rosalia (syn. Leontideus rosalia) from the Oklahoma City Zoo. J. Zoo. An. Med., 11: 77-80.

YUE, M. Y. \& JORDAN, H. E., 1986, Studies of the life cycle of Pterygodermatites nycticebi (Monning, 1920) Quentin, 1969. J. Parasitol., 72: 788-790. 